\title{
Inhaled frusemide and exercise induced asthma: evidence of a role for inhibitory prostanoids
}

\author{
I D Pavord, A Wisniewski, A E Tattersfield
}

\begin{abstract}
Background Inhaled frusemide protects subjects with asthma against a wide range of bronchoconstrictor challenges, including allergen, exercise and inhaled sodium metabisulphite. An investigation was designed to determine whether this protection is related to the production of inhibitory prostaglandins, such as prostaglandin $\mathrm{E}_{2}\left(\mathrm{PGE}_{2}\right)$, by studying the effect of the cyclooxygenase inhibitor indomethacin on the protection afforded by inhaled frusemide against exercise induced asthma.
\end{abstract}

Methods In a double blind crossover study 10 subjects with mild asthma were pretreated with indomethacin $(50 \mathrm{mg}$ thrice daily) or placebo capsules for three days; they then inhaled frusemide (40 $\mathrm{mg}$ ) or placebo 10 minutes before an exercise test previously shown to cause a $20-30 \%$ fall in forced expiratory volume in one second $\left(\mathrm{FEV}_{1}\right)$.

Results After inhalation of placebo exercise caused a similar maximum fall in $F_{E V}$ whether pretreatment was with placebo $(26 \%)$ or indomethacin $(25 \cdot 2 \%)$. After inhalation of frusemide the maximum fall in $\mathrm{FEV}_{1}$ was reduced to $14.3 \%$ after placebo pretreatment and to $21 \cdot 8 \%$ after indomethacin pretreatment; the difference between placebo and indomethacin pretreatment was significant (mean difference $7.5 \%$, 95\% limits $0.6 \%$, $14 \cdot 4 \%)$. The inhibitory effect of frusemide on the response to exercise, assessed as change in $F E V_{1}$ over 30 minutes, was significantly greater with placebo $(62 \%)$ than indomethacin (13\%) pretreatment. Conclusion These findings support a role for inhibitory prostanoids, such as $\mathrm{PGE}_{2}$, in the beneficial effects of frusemide as a protection against exercise induced asthma.

(Thorax 1992;47:797-800)

Respiratory Medicine Unit, City Hospital, Nottingham NG5 1PB I D Pavord A Wisniewski A E Tattersfield Reprint requests to: Dr I D Pavord

Received 2 January 1992 Returned to authors 21 February 1992 Revised version received 4 March 1992 Accepted 5 March 1992 asthma is uncertain but is of interest as it might shed light on the pathophysiology of asthma. ${ }^{7}$ One possibility is that frusemide inhibits epithelial sodium-potassium-chloride $(\mathrm{Na} / \mathrm{K} / \mathrm{Cl})$ cotransport and thereby alters neural activity ${ }^{4}$ or inflammatory cell activation ${ }^{35}$ through a direct action or by altering the osmolarity of airway lining fluid. The lack of effect of systemic frusemide in asthma argues against this mechanism, however, ${ }^{7}$ as does the fact that bumetanide, a more potent inhibitor of $\mathrm{Na} / \mathrm{K} / \mathrm{Cl}$ cotransport, has no effect on asthma induced by sodium metabisulphite or exercise. ${ }^{910}$

We have explored an alternative hypothesis -namely, that the effects of frusemide are due to generation of cyclooxygenase products in the airway. Frusemide enhances synthesis of prostaglandin $\mathrm{E}_{2}\left(\mathrm{PGE}_{2}\right)$, ${ }^{11}$ and intrarenal synthesis of this prostanoid is thought to play a part in the acute vascular changes observed after intravenous administration of frusemide. ${ }^{12}$ There is evidence that bumetanide does not share these effects when administered at equivalent diuretic doses. ${ }^{13}$ As inhaled $\mathrm{PGE}_{2}$ has been shown to protect against sodium metabisulphite and exercise induced asthma and the early response to allergen, ${ }^{14-16}$ the beneficial effects of inhaled frusemide may be related to local airway production of $\mathrm{PGE}_{2}$. We report the effect of the cyclooxygenase inhibitor indomethacin on the protection afforded by inhaled frusemide against exercise induced asthma.

\section{Methods}

SUBJECTS

We studied 10 subjects (eight male) aged 18-52 years, with mild stable atopic asthma and a $20 \%$ or more fall in $\mathrm{FEV}_{1}$ with exercise, who required only inhaled drugs. All subjects were taking an inhaled $\beta_{2}$ agonist and five an inhaled corticosteroid (100-1000 $\mu \mathrm{g}$ beclomethasone a day). One subject was a current smoker and one a past smoker. All had a baseline forced expiratory volume in one second $\left(\mathrm{FEV}_{1}\right)$ of $.70 \%$ predicted or more. None gave a history of aspirin induced asthma or developed bronchoconstriction in response to oral indomethacin when challenged in the laboratory. $\beta_{2}$ Agonists were withheld for six hours before each exercise test. Subjects gave full signed consent to participate in the study, which was approved by the City Hospital ethics committee. 
Mean (95\% confidence interval) values for baseline FEV, maximum fall in FEV, and change in FEV, over 30 minutes ( $A U C$ ) for indomethacin and frusemide treatment, and within subject differences from indomethacin and frusemide for the other three treatment regimens

\begin{tabular}{|c|c|c|c|c|}
\hline \multirow[b]{2}{*}{ Treatment } & \multirow{2}{*}{$\begin{array}{l}\text { Indomethacin } \\
+ \text { frusemide } \\
\text { (mean values) }\end{array}$} & \multicolumn{3}{|c|}{ Mean differences from indomethacin + frusemide } \\
\hline & & $\begin{array}{l}\text { Placebo+ } \\
\text { frusemide }\end{array}$ & $\begin{array}{l}\text { Indomethacin }+ \\
\text { placebo }\end{array}$ & $\begin{array}{l}\text { Placebo + } \\
\text { placebo }\end{array}$ \\
\hline Baseline $\mathrm{FEV}_{\mathrm{I}}(\mathrm{l})$ & $3 \cdot 26$ & $\begin{array}{l}-0.09 \\
(0 \cdot 07,-0 \cdot 25)\end{array}$ & $\begin{array}{l}-0 \cdot 13 \\
(0 \cdot 03,-0 \cdot 29)\end{array}$ & $\begin{array}{l}-0 \cdot 08 \\
(0 \cdot 09,-0 \cdot 24)\end{array}$ \\
\hline Maximum fall in $\mathrm{FEV}_{1}(\%)$ & $21 \cdot 8$ & $\begin{array}{l}-7 \cdot 5 \\
(-0.6,-14 \cdot 4) \\
p<0.05\end{array}$ & $\begin{array}{l}3 \cdot 5 \\
(-3 \cdot 5,10 \cdot 4)\end{array}$ & $\begin{array}{l}4 \cdot 3 \\
(-2 \cdot 6,11 \cdot 2)\end{array}$ \\
\hline AUC & 393 & $\begin{array}{l}-225 \\
(-45,-405) \\
p<0.02\end{array}$ & $\begin{array}{l}121 \\
(-59,301)\end{array}$ & $\begin{array}{l}89 \\
(-91,268)\end{array}$ \\
\hline
\end{tabular}

\section{TESTS}

Subjects attended for one or two assessment visits, during which practice exercise tests were performed and the work load necessary to produce a $20-30 \%$ fall in $\mathrm{FEV}_{1}$ was established. Subjects exercised for seven minutes at room temperature on an electric treadmill (Case 12, Marquette Electronics Inc, Milwaukee) while breathing dry air through a mouthpiece connected to a Collins triple J valve, Douglas bag reservoir, and air cylinder. $\mathrm{FEV}_{1}$ was measured on a dry bellows spirometer (Vitalograph, Buckingham) and the higher of two successive readings within $100 \mathrm{ml}$ was recorded.

\section{PROTOCOL}

Subjects attended for an identical exercise test on four study days four to seven days apart at the same time of day. Before each visit the subject was asked to take indomethacin $50 \mathrm{mg}$ three times daily or matched placebo for two days before and on the day of the challenge, the last dose being taken one hour before the

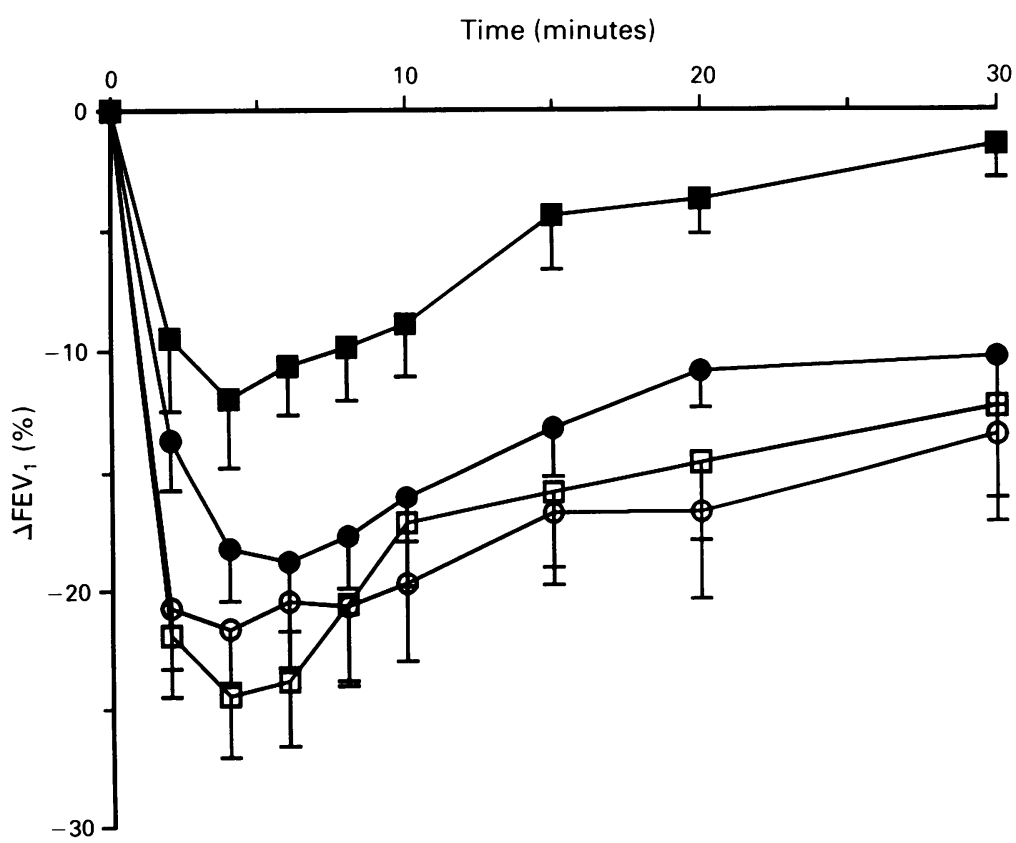

Percentage change in $F E V,\left(\triangle F E V_{1}\right)$ against time after exercise. Points represent mean (SEM) percentage change at each time point. Closed circle-indomethacin and inhaled frusemide; open circle-indomethacin and inhaled placebo; closed square-placebo and inhaled frusemide; open square-placebo and inhaled placebo. exercise test. Ten minutes before the exercise test subjects inhaled frusemide $40 \mathrm{mg}$ (made up to $5 \mathrm{ml}$ with normal saline) or placebo solution (normal saline matched for $\mathrm{pH}$ and osmolarity) via a Medix electronic nebuliser (output $1 \mathrm{ml}$ / min). Subjects inhaled through a face mask at tidal volume until the nebuliser was dry. $\mathrm{FEV}_{1}$ measurements were taken before and five and 10 minutes after inhalation and at intervals for 30 minutes after exercise.

\section{ANALYSIS}

The airway response to exercise was assessed as the maximum percentage fall in $\mathrm{FEV}_{1}$ and as the area under the plot of percentage change in $\mathrm{FEV}_{1}$ against time (AUC), the $\mathrm{FEV}_{1}$ immediately before exercise $(10$ minutes after inhalation) being used as baseline. Baseline $\mathrm{FEV}_{1}$, maximum percentage fall in $\mathrm{FEV}_{1}$, and AUC were compared within subjects by analysis of variance by means of the generalised linear interactive modelling (GLIM) statistical package. $\mathrm{FEV}_{1}$ values before and after inhalation were compared by a paired $t$ test. The inhibitory effect of frusemide on exercise induced asthma was estimated by expressing the difference in AUC over 30 minutes between the treatment and placebo day as a percentage of the placebo AUC. The percentage inhibition was not normally distributed and is expressed as a median and range; it was compared within subjects by the Wilcoxon signed rank sum test.

\section{Results}

There was a small increase in $\mathrm{FEV}_{1}$ after inhalation of frusemide following indomethacin pretreatment (mean $0 \cdot 161,95 \%$ confidence limits (CL) 0.035, 0.289; p < 0.02) but the pre-exercise (baseline) $\mathrm{FEV}_{1}$ did not differ on any of the treatment days (table).

After inhalation of placebo exercise caused a similar mean maximum fall in $\mathrm{FEV}_{1}$ with placebo pretreatment $(26 \%)$ and indomethacin pretreatment $(25.2 \%)$. After inhalation of frusemide with placebo pretreatment the mean maximum fall in FEV , was reduced to $14.3 \%$ $(\mathrm{p}<0.01)$. When frusemide was given with indomethacin pretreatment the fall in FEV was $21.8 \%$, which did not differ from the mean maximum fall on either of the placebo inhalation days (table and figure). It did, however, differ significantly from the fall after frusemide 
with placebo pretreatment (mean difference $7 \cdot 5 \%, 95 \%$ CL $0.6,14 \cdot 4 \%$; $<<0.05)$.

The area under the plot of change in $\mathrm{FEV}_{1}$ against time following frusemide was compared with that following placebo inhalation and pretreatment. The median reduction in AUC after frusemide was $62 \%$ with placebo pretreatment and $13 \%$ with indomethacin pretreatment; the difference was significant $(\mathrm{p}<0.01)$.

\section{Discussion}

This study has confirmed that inhaled frusemide protects against exercise induced asthma. The $62 \%$ reduction in the airway response to exercise after inhaled frusemide is in agreement with the findings of Bianco et al ${ }^{1}$ and others. ${ }^{10}$ We also confirmed that indomethacin alone, at a dose that abolished the rise in urinary thromboxane metabolites ${ }^{17}$ and increase in prostaglandin concentrations in bronchoalveolar lavage fluid ${ }^{18}$ after allergen challenge in asthmatic subjects, has no effect on the airway response to exercise. ${ }^{19}$ Our main finding was that treatment with indomethacin for three days reduced the effect of frusemide in protecting against exercise induced asthma. This reversal of the protective effects of frusemide by a cyclooxygenase inhibitor provides strong evidence for our hypothesis that the beneficial effects of frusemide in exercise induced asthma are due to production of inhibitory prostanoids.

Both $\mathrm{PGE}_{2}$ and prostacyclin $\left(\mathrm{PGI}_{2}\right)$ are major cyclooxygenase products of human lung $^{20}$ and in animals frusemide has been shown to enhance synthesis of $\mathrm{PGE}_{2}$ by renal tubular epithelium ${ }^{11}$ and $\mathrm{PGI}_{2}$ by vascular endothelium. ${ }^{21}$ In man $\mathrm{PGE}_{2}$ is produced by airway epithelium ${ }^{22}$ and $\mathrm{PGI}_{2}$ by pulmonary vascular tissue..$^{20}$ As frusemide is only effective in asthma when inhaled, enhanced production of epithelium derived $\mathrm{PGE}_{2}$ is the more likely mechanism.

This mechanism is consistent with the lack of effect of bumetanide in asthma. Bumetanide, like frusemide, inhibits the $\mathrm{Na} / \mathrm{K} / \mathrm{Cl}$ cotransporter but, in contrast to frusemide, does not inhibit the airway response to exercise ${ }^{10}$ or inhaled sodium metabisulphite. ${ }^{9}$ Intrarenal synthesis of $\mathrm{PGE}_{2}$ in response to frusemide is thought to play a part in the vascular changes observed after intravenous frusemide. ${ }^{11223}$ Frusemide stimulates production of $\mathrm{PGE}_{2}$ by increasing availability of arachidonic $\mathrm{acid}^{23}$ and it may in addition inhibit the conversion of $\mathrm{PGE}_{2}$ to $\mathrm{PGF}_{2 x}$ by $\mathrm{PGE}_{2}-9$-ketoreductase ${ }^{24}$ and the metabolism of $\mathrm{PGE}_{2}$ by $\mathrm{PGE}_{2}-15-$ hydroxydehydrogenase. ${ }^{24}{ }^{25}$ Bumetanide has no effect on the latter enzyme ${ }^{25}$ and this, together with the absence of peripheral vascular changes after intravenous bumetanide, ${ }^{13}$ suggests that frusemide has a greater effect on prostaglandin synthesis than bumetanide in relation to $\mathrm{Na} / \mathrm{K}$ / $\mathrm{Cl}$ cotransport.

Our suggestion that frusemide is acting through release of inhibitory prostanoids assumes that these prostanoids protect predominantly against bronchoconstrictor challenges that act indirectly (through mast cell degranulation, neural pathways, or inflammatory cells) rather than those that act directly on airway smooth muscle. There is some evidence to support this view. $\mathrm{PGE}_{2}$ does not inhibit histamine induced contractions of human airway preparations in vitro and may cause contraction rather than relaxation. ${ }^{26}$ $\mathrm{PGE}_{2}$ does, however, have inhibitory effects on cholinergic contractions of human airway preparations after electric field stimulation ${ }^{27}$ and in higher concentrations on lung mast cell mediator release ${ }^{28}$ and eosinophil activation. ${ }^{29}$ Inhaled $\mathrm{PGE}_{2}$ inhibits the bronchoconstrictor response to exercise, ultrasonically nebulised distilled water, ${ }^{15}$ allergen, ${ }^{16}$ and sodium metabisulphite in subjects with mild asthma but has little or no effect on bronchial reactivity to methacholine. ${ }^{14}$ Studies with cyclooxygenase inhibitors support a protective role for endogenous inhibitory prostanoids, showing a reduction in the refractoriness commonly observed after recovery from bronchoconstriction induced by exercise ${ }^{19}$ and other indirect challenges. ${ }^{30} 31$

The fall in $\mathrm{FEV}_{1}$ after exercise with frusemide was greater after indomethacin than placebo despite a small increase in $\mathrm{FEV}_{1}$ on the indomethacin treatment day after inhalation of frusemide. The mechanism of this small bronchodilator response is not clear but it may represent an effect of frusemide that is independent of cyclooxygenase products.

We considered whether the interaction between indomethacin and frusemide could be explained on grounds other than inhibition of prostaglandin synthesis. Both drugs are weak organic acids and may compete for a similar transport system across the airway epithelium. This seems unlikely, however, as frusemide is effective only when inhaled, suggesting that it acts on the luminal surface of the epithelium; and such competition does not appear to occur in the kidney, where indomethacin has no effect on renal excretion of frusemide. ${ }^{11}$

Of the various theories that have been advanced to explain the mode of action of frusemide, none is able to explain fully its wide range of action in asthma, the lack of protection seen with bumetanide, and the fact that frusemide appears to be effective only when inhaled. Studies suggesting that it acts on neurally mediated bronchoconstriction ${ }^{832}$ do not explain the effects of frusemide on the early and late response to allergen. ${ }^{5}$ The attraction of our hypothesis that the effects of frusemide in asthma are due to production of an inhibitory prostanoid such as $\mathrm{PGE}_{2}$ is that it offers a plausible explanation for all of these effects.

We thank Mrs S Pacey for coding the drugs and Mrs J Williams and Mrs S Cooper for technical support. The helpful advice from Drs J Britton and A Knox is also much ap
supported by the Medical Research Council.

1 Bianco S, Vaghi A, Robuschi M, Pasargiklian M. Prevention of exercise-induced bronchoconstriction by inhaled frusemide. Lancet 1988;ii:252-5.

2 Robuschi M, Gambard G, Spagnotto S, Vaghi A, Bianco S. Inhaled frusemide is highly effective in preventing Inhaled frusemide is highly effective in preventing
ultrasonically nebulised water bronchoconstriction. Pulm Pharmacol 1989;1:187-91. 
3 Polosa R, Lau LCK, Holgate ST. Inhibition of adenosine 5'monophosphate and methacholine-induced bronchoconstriction in asthma by inhaled frusemide. Eur Respir 1990;3:665-72.

4 Nichol GM, Alton EWFW, Nix A, Geddes DM, Chung KF Barnes PJ. Effect of inhaled furosemide on metabisulfite and methacholine-induced bronchoconstriction and nasal potentials in asthmatic subjects. Am Rev Respir Dis 1990;142:576-80.

5 Bianco S, Pieroni MG, Refini RM, Rottoli L, Sestini P. Protective effect of inhaled furosemide on allergeninduced early and late asthmatic reactions. $N \mathrm{Engl} \mathrm{J} \mathrm{Med}$ 1989;321:1069-73.

6 Vaghi A, Robuschi M, Berni F, Bianco S. Effect of inhaled frusemide $(F)$ on bronchial response to histamine $(H)$ in asthmatics. Eur Respir J 1988;1(suppl 2):406S.

7 Anonymous. Inhaled frusemide and asthma [Editorial] Lancet 1990;335:944-6.

8 Elwood W, Lotvall JO, Barnes PJ, Chung KF. Loop diuretics inhibit cholinergic and noncholinergic nerves in guinea pig airways. Am Rev Respir Dis 1991;143:1340-4.

9 O'Connor BJ, Chung KF, Chen-Wordsdell YM, Fulle RW, Barnes PJ. Effect of inhaled furosemide and bumetanide on adenosine 5 -monophosphate and sodium metabisulfite-induced bronchoconstriction in asthmatic subjects. Am Rev Respir Dis 1991;143:1329-33.

10 Duggan CJ, Dixon CMS, Ind PW. The effect of furosemide and bumetanide in exercise-induced asthma (EIA) [abstract]. Am Rev Respir Dis 1990;141(4 part 2):A474.

11 Miyanoshita A, Terada $M$, Endou $H$. Furosemide directly stimulates prostaglandin $E_{2}$ production in the thick ascending limb of Henle's loop. J Pharmacol Exp Ther 1989;251:1155-9.

12 Johnston GD, Hiatt WR, Nies AS, Payne NA, Murphy RC Gerber JG. Factors modifying the early nondiuretic vascular effects of frusemide in man. The possible role of renal prostaglandins. Circ Res 1983;53:630-5.

13 Johnston GD, Nicholls DP, Kondowe GB, Finch MB. Comparison of the acute vascular effects of frusemide and bumetanide. Br J Clin Pharmacol 1986;21:359-64.

14 Pavord ID, Wisniewski A, Mathur R, Wahedna I, Knox A, Tattersfield AE. Effect of inhaled prostaglandin $E_{2}$ on bronchial reactivity to sodium metabisulphite and methacholine in subjects with asthma. Thorax 1991;46:633-7.

15 Pasargiklian M, Bianco S, Allegra L, Moavero NE, Petrigni $\mathrm{G}$, Robuschi $\mathrm{M}$, et al. Aspects of bronchial reactivity to prostaglandins and aspirin in asthmatic patients. Respiration 1977;34:79-91

16 Pasargiklian M, Bianco S, Allegra L. Clinical, functional and pathogenetic aspects of bronchial reactivity to prostaglandins $\mathrm{F}_{2}, \mathrm{E}_{1}$ and $\mathrm{E}_{2}$. Advances in Prostaglandin and Thromboxane Research 1976;1:461-75.

17 Sladek K, Dworski R, Fitzgerald GA, Buitkus KL, Block FJ, Marney SR, et al. Allergen-stimulated release of thromboxane $A_{2}$ and leukotriene $E_{4}$ in humans. Effect of indomethacin. Am Rev Respir Dis 1990;141:1441-5.

18 Dworski R, FitzGerald G, Roberts L, Oates J, Schwartz L, Sheller JR. Eicosanoid formation in atopic human lung: effect of indomethacin. Am Rev Respir Dis 1988;137:375.

19 O'Byrne PM, Jones GL. The effect of indomethacin on exercise-induced bronchoconstriction and refractorines after exercise. Am Rev Respir Dis 1986;134:69-72.

20 Holtzman MJ. Arachidonic acid metabolism. Implications of biological chemistry for lung function and disease. $A m$ Rev Respir Dis 1991;143:188-203.

21 Lundergan CF, Fitzpatrick TM, Rose JC, Ramwell RN Kot PA. Effect of cyclooxygenase inhibition on the pulmonary vasodilator response to furosemide. J Pharmacol Exp Ther 1988;246:102-6.

22 Churchill L, Chilton FH, Resau JH, Bascom R, Hubbard WC, Proud D. Cyclooxygenase metabolism of endogenous arachidonic acid by cultured human trachea epithelial cells. Am Rev Respir Dis 1989;140:449-54.

23 Weber PC, Scherer B, Larsson C. Increase of free arachidonic acid by frusemide in man as the cause of prosta landin and renin release. Eur $J$ Pharmacol 1977;41: 329-32.

24 Stone KJ, Hart M. Inhibition of renal $\mathrm{PGE}_{2}-9$-ketoreductase by diuretics. Prostaglandins 1976;12:197-207.

25 Oliw E. Prostaglandins and kidney function. Acta Physiol Scand 1979;461(suppl): 1-55.

26 Haye-Legrand I, Cerrina J, Raffestin B, Labat C, Boullet C Bayol A, et al. Histamine contractions of isolated human airway smooth muscle preparations: role of prostaglandins. J Pharmacol Exp Ther 1986;239:536-41.

27 Ito I, Suzuki H, Aizawa H, Hirose T, Hakoda H. Prejunctional inhibitory action of prostaglandin $E_{2}$ on excitatory neuro-effector transmission in the human bronchus. Prostaglandins 1990;39:639-55.

28 Peters SP, Schulman ES, MacGlashan DW, Schleimer RP Newball HH, Lichtenstein LM. Pharmacological and biochemical studies of human lung mast cells. J Allergy Clin Immunol 1982;69:150.

29 Giembycz MA, Kroegel C, Barnes PJ. Prostaglandin E inhibits platelet activating factor-induced eosinophil activation [abstract]. Am Rev Respir Dis 1990;141(4 part 2):A396.

30 Mattoli S, Foresi A, Corbo GM, Valente S, Ciappi G. The effect of indomethacin on the refractory period occurring after the inhalation of ultrasonically nebulized distilled water. J Allergy Clin Immunol 1987;79:678-83.

31 Dorsch W, Frey L. Allergen tachyphylaxis of guinea pigs in vivo: a prostaglandin E mediated phenomenon? NaunynSchmiedeberg's Arch Pharmacol 1981;317:351-6.

32 Ventresca PG, Nichol GM, Barnes PI, Chung KF. Inhaled furosemide inhibits cough induced by low chloride content solutions but not by capsaicin. Am Rev Respir Dis 1990;142:143-6. 